Relations industrielles

Industrial Relations

\title{
Gunderson, Morley, and Allen Ponak, Union-Management Relations in Canada, 3rd edition
}

\section{Joseph B. Rose}

Volume 51, numéro 1, 1996

URI : https://id.erudit.org/iderudit/051082ar

DOI : https://doi.org/10.7202/051082ar

Aller au sommaire du numéro

Éditeur(s)

Département des relations industrielles de l'Université Laval

ISSN

0034-379X (imprimé)

1703-8138 (numérique)

Découvrir la revue

Citer ce compte rendu

Rose, J. B. (1996). Compte rendu de [Gunderson, Morley, and Allen Ponak, Union-Management Relations in Canada, 3rd edition]. Relations industrielles / Industrial Relations, 51(1), 210-211. https://doi.org/10.7202/051082ar

Tous droits réservés (C) Département des relations industrielles de l'Université Laval, 1996
Ce document est protégé par la loi sur le droit d'auteur. L'utilisation des services d'Érudit (y compris la reproduction) est assujettie à sa politique d'utilisation que vous pouvez consulter en ligne.

https://apropos.erudit.org/fr/usagers/politique-dutilisation/ 


\section{Recensions}

\section{Book Reviews}

\section{Union-Management Relations in Canada, 3rd edition}

edited by Morley GUNDERSON and Allen PONAK, Don Mills, Ontario, Addison-

Wesley Publishers, 1995, 560 p., ISBN 0-201-76607-8.

In reviewing this book I had occasion to refer to Gene Swimmer's review of the second edition of this book. Swimmer praised the editors for adding so much new material and concluded the changes represented "a major improvement over the original volume (a good text in its own right)". The third edition represents a further improvement. Given this text will be familiar to most readers of this review, I do not intend to provide a detailed account of each chapter. Suffice it to say the book follows a modified systems approach to industrial relations and the organization of the book is essentially the same as in previous editions. My review will focus on the changes introduced in this edition as well as an assessment of the book's strengths and shortcomings.

It has been six years since the second edition was published and much has changed in the intervening years. Appropriately, the editors sought to capture the changing landscape by commissioning two new chapters (Carla Lipsig-Mumme's chapter on labour strategies in a changing environment and Anil Verma's chapter on employee involvement) and (2) overhauling existing chapters (through revisions, updates and, where new authors were involved, rewriting the chapters).

The new chapters work well. LipsigMumme's chapter injects a political economy perspective to the state of unionism and its future. One of the chapter's strengths, is its account of the unravelling of the labour relations system over the past two decades and the substantial challenges facing the labour movement. Verma's chapter provides a comprehensive review of need for and the extent and nature of workplace change. It includes a review of the impediments to employee involvement plans, union involvement in such schemes and the role of public policy in fostering workplace change.

Turning to the "same title/new authors" chapters, there are several instances where the book has been significantly strengthened. The most dramatic improvement is Mark Thompson's chapter on the management of industrial relations. Unlike the former chapter (which was based on U.S. experience and lacked Canadian content), Thompson's paper is based on his interviews with senior industrial relations executives in major Canadian firms. It provides a rich and detailed account of management strategies, policies and practices and demonstrates that Canadian managers have adopted a more accommodative approach to unions and collective bargaining than their American counterparts. Gregor Murray's chapter on unions contains valuable additions, notably in the concluding section on union actions at the workplace level and beyond (economic and political voice mechanisms on behalf of all workers). The revised chapter on grievances and their resolution by Ken Thornicroft and Genevieve Eden benefits from a broader survey of practice in Canada, a greater emphasis on innovative rights 
disputes procedures (including grievance mediation and expedited arbitration) and a more thorough review of research findings on grievance procedures and arbitration. I would have preferred to see less emphasis placed on relatively narrow issues like "gender effects" and more attention devoted to issues such as the consequences of grieving (as per David Lewin and Richard Peterson's book, The Modern Grievance Procedure). Finally, Richard Chaykowski has written a hybrid version of the former chapters on the structure and process of collective bargaining. The chapter is crisp, well written and provides a good overview of the negotiating process. The section on bargaining structure is however, threadbare and would have benefitted from retaining (in an abbreviated form) the former sections on the concept, determinants and consequences of bargaining structure. As well, the chapter should illustrate the frequency of bargaining structures, even if the data are limited to bargaining units of 500 or more employees. Overall, the "same title/new authors" chapters represent a positive addition to the third edition.

The remainder of the book consists of "same title/same author" chapters (in some cases, with a new co-author). In many, but not all cases, these chapters have been revised and updated to effectively capture and interpret the changing industrial relations scene. Notable examples include: the public sector chapter (by Allen Ponak and Mark Thompson) includes updated strike and compensation data and a review of recent wage restraint measures; the chapter on Quebec (by Jean Boivin and Esther Deom) includes a section on the industrial relations context and adds a section on public policy covering labour standards, workplace equity and health and safety; Roy Adams' chapter on Canada in comparative perspective adds new material on globalization, competitiveness, free trade, and the relationship between labour relations and economic performance; and the chapter on the collective agreement (Anthony Giles and Akivah Starkman) contains updated figures on collective agreement coverage and remains one of the best treatments of the subject. It must be added, however, that some chapters have not changed significantly and arguably could have. Examples include the chapters on collective bargaining law (Don Carter), employment law (David McPhillips and Geoffrey England) and labour history (Desmond Morton).

Let me add a few general comments. First, I have never felt completely comfortable trying to "fit" this book into courses. Some chapters seem better suited to an introductory IR course, while other chapters appear more suitable to a collective bargaining course. Second, whereas most chapters are very readable, there are instances where the narrative flow bogs down. For example, the section of the strike chapter dealing with strike determinants tries to incorporate too many studies and is shrouded in econometric jargon. I suspect student readers will conclude "more is less". Third, the editors, through their editorial prowess and contributions to individual chapters, have once again produced an excellent volume of readings. Fourth, this edition looks great: the print is large, the tables and figures are clear and the pages are not overcrowded.
JOSEPH B. ROSE McMaster University 